\title{
PENINGKATAN KEMAMPUAN PENGGUNAAN EJAAN DAN TANDA BACA DALAM MENULIS TEKS LAPORAN OBSERVASI DENGAN METODE JIGSAW
}

\author{
Sibawae ${ }^{1, *}$ \\ 1 Universitas Pendidikan Ganesha
}

\section{Abstrak}

Penelitian ini bertujuan meningkatkan kemampuan menggunakan ejaan dan tanda baca dalam menulis teks laporan hasil observasi dengan metode Jigsaw siswa kelas X IPS SMA Negeri 1 Singaraja tahun pelajaran 2017/2018.Penelitian ini adalah penelitian tindakan kelas yang dilaksanakan dalam dua siklus, yang terdiri dari rencana tindakan, pelaksanaan tindakan, observasi atau evaluasi dan refleksi. Subjek penelitian peserta didik kelas X IPS SMA Negeri 1 Singaraja, berjumlah 27 orang dengan rincian 14 orang putra dan 13 orang putri. Data dianalisis menggunakan statistik deskriptif. Permasalahan penelitian ini adalah rendahnya kemampuan dalam menggunakan ejaan dan tanda baca siswa kelas X IPS SMA Negeri 1 Singaraja dalam menulis teks laporan hasil observasi. Hal tersebut dilihat dari data: 1)kesalahan penulisan huruf kapital sejumlah 61 kesalahan, 2) kesalahan preposisi atau kata depan sejumlah 67 kesalahan, 3) kesalahan tanda koma sejumlah 117, 4) dan kesalahan tanda titik sejumlah 41 kesalahan. Setelah dilaksanakan penelitian menggunakan metode Jigsaw diperoleh hasil, yaitu siswa yang melakukan kesalahan dalam penggunaan ejaan dan tanda baca menurun dari 172 pada siklus I menjadi 52 kesalahan pada siklus II. Apabila diklasifikasikan, yaitu 1) kesalahan penggunaan huruf kapital/kecil mengalami penurunan dari 47 kesalahan pada siklus I menjadi 12 kesalahan pada siklus II, 2) siswa yang melakukan kesalahan penggunaan kata depan dari 31 kesalahan pada siklus I menjadi 10 kesalahan pada siklus II, 3) Siswa yang melakukan kesalahan penggunaan tanda baca berupa koma (,) dari 70 kesalahan pada siklus I menjadi 20 kesalahan pada siklus II. 4) Siswa yang melakukan kesalahan penggunaan tanda baca berupa titik (.) dari 24 kesalahan pada siklus I menjadi 10 kesalahan pada siklus II. Respons siswa juga meningkat dari rata-rata 57 pada siklus I menjadi 63 pada siklus II. Walaupun masih dalam kriteria yang sama, yaitu kriteria positif.
\end{abstract}

\author{
Keywords: \\ Peningkatan \\ kemampuan penggunaan \\ ejaan dan tanda baca, \\ metode Jigsaw.
}

\section{PENDAHULUAN}

Pembelajaran bahasa Indonesia di kelas X IPS SMA Negeri 1 Singaraja pada kompetensi dasar 4.2 " Mengonstruksi teks laporan hasil observasi dengan memerhatikan isi dan aspek kebahasaan" menunjukkan kendala yaitu masih banyaknya siswa melakukan kesalahan dalam aspek kebahasaan berupa penggunaan ejaan dan tanda baca pada waktu menulis teks laporan hasil observasi. Setelah produk berupa tulisan teks laporan hasil observasi siswa dikoreksi guru hasilnya ditemukan kesalahan penulisan huruf kapital sejumlah 61 kesalahan, kesalahan preposisi atau kata depan sejumlah 67 kesalahan, kesalahan tanda koma sejumlah 117, dan kesalahan tanda titik sejumlah 41 kesalahan.

Aktivitas menulis tidak hanya berkaitan dengan tertuangnya ide dalam bentuk tulisan. Masalah penggunaan ejaan dan tanda baca dalam menulis juga merupakan salah satu syarat agar tulisan tersebut dapat mengomunikasikan gagasan penulis kepada pembaca. Oleh karena itu, di dalam pembelajaran menulis siswa perlu dibiasakan untuk dapat memahami kaidah penggunaan ejaan dan tanda baca sesuai dengan EYD dan menerapkannya dalam praktik menulis.

Permasalahan ejaan dan tanda baca acap kali dipandang sebagai permasalahan yang sepele. Namun, dalam praktiknya masih banyak terjadi kesalahan. Hal ini sebagaimana dikemukakan Hasnun (2006:16) bahwa usia EYD sudah lebih dari dua dasawarsa. Akan tetapi, sampai sekarang masih dijumpai banyak kesalahan penggunaan ejaan dan tanda baca. Kesalahan tersebut juga banyak dijumpai dalam karangan-karangan ilmiah dan surat-surat resmi. 
Permasalah penggunaan ejaan dan tanda baca dalam menulis teks laporan hasil observasi pada siswa Kelas X IPS SMA Negeri 1 Singaraja perlu dipecahkan dengan metode Jigsaw yang digagas oleh Elliot. Menurut Slavin (1995:122) inti dari gagasan Elliot ini adalah menyadari betapa pentingnya pembelajaran secara kooperatif. Teman satu kelas bukanlah rival yang harus selalu dikalahkan atau mengalahkan teman lain. Pembelajaran di kelas merupakan wahana untuk dapat menjalin kerja sama antarsiswa. Tidak ada kelas yang benar-benar homogen. Heterogenitas kelas, justru merupakan peluang untuk saling memberi dan menerima, antara siswa yang memiliki pengetahuan lebih dan siswa yang berpengetahuan kurang.

Menurut keterangan guru bahasa Indonesia di SMA Negeri 1 Singaraja sebagian besar siswa tidak memerhatikan ejaan dalam menulis teks laporan hasil observasi. Hal ini dapat dilihat dari banyaknya kesalahan siswa dalam penulisan huruf capital dan kecil, kata depan, tanda baca berupa titik dan koma. Padahal disetiap pembelajaran guru akan meminta untuk menulis teks yang akan diajarkan berdasarkan EYD.

Berdasarkan permasalahan-permasalahan tersebut, perlu dilakukan penelitian mengenai penerapan metode Jigsaw pada mata pelajaran bahasa Indonesia dalam rangka membantu peningkatan kemampuan menggunakan ejaan khsusnya penggunaan huruf kapital, preposisi, tanda titik (.), dan tanda koma (,) dalam menulis teks laporan hasil observasi pada siswa kelas X IPS SMA Negeri 1 Singaraja dengan judul, "Peningkatan Kemampuan Penggunakan Ejaan dan Tanda Baca dalam Menulis Teks Laporan Observasi dengan Metode Jigsaw Siswa Kelas X IPS SMA Negeri 1 Singaraja Tahun Pelajaran 2017/2018".

\section{METODE PENELITIAN}

Penelitian ini menggunakan rancangan penelitian tindakan kelas dan dilakukan dalam multisiklus. Dalam penelitian ini, peneliti merancang metode penelitian meliputi refleksi awal, perencanaan tindakan, pelaksanaan tindakan, observasi/ evaluasi, dan refleksi. Subjek dalam penelitian ini adalah siswa kelas $\mathrm{X}$ IPS SMA Negeri 1 Singaraja. Pengambilan subjek penelitian ini dipilih berdasarkan observasi awal yang telah dilakukan oleh peneliti dan pada kenyataannya banyak siswa yang salah dalam menggunaka tanda baca dan ejaan.

Objek penelitian merupakan hal yang dikaji dalam penelitian tersebut. Objek penelitian dibedakan atas dua macam, yaitu objek yang mencerminkan proses dan objek yang mencerminkan produk. Sehubungan dengan pernyataan tersebut, objek proses dalam penelitian ini adalah (a) apakah penerapan metode jigsaw dapat meningkatkatkan kemampuan penggunaan ejaan dan tanda baca dalam menulis teks laporan hasil observasi pada siswa kelas X IPS SMA Negeri 1 Singaraja, (b) Bagaimanakah respons siswa kelas X IPS SMA Negeri 1 Singaraja dalam penerapan metode jigsaw, (c) Bagaimanakah penerapan metode jigsaw yang tepat dalam meningkatkatkan kemampuan penggunaan ejaan dan tanda baca dalam menulis teks laporan hasil observasi pada siswa kelas X IPS SMA Negeri 1 Singaraja.

Metode pengumpulan data yang digunakan dalam penelitian ini adalah metode tes, metode observasi, metode kuesioner, dan metode wawancara. Data dianalisis dengan menggunakan teknik deskriptif kuantitatif dan deskriptif kualitatif. Penelitian tindakan kelas (PTK) ini mengandung data kualitatif dan data kuantitatif. Data kualitatif berupa data aktivitas belajar mengajar selama dalam proses menulis teks laporan hasil observasi dengan memerhatikan penggunaan ejaan dan tanda baca menggunakan metode Jigsaw. Data kuantitatif berupa tingkat kemampuan siswa yang ditunjukkan dengan jumlah kesalahan dalam penggunaan ejaan dan tanda baca, aktivitas belajar mengajar, dan respons siswa. Sesuai dengan data tersebut, penelitian ini menggunakan empat metode, yakni metode tes, metode observasi, metode kuesioner, dan metode wawancara. Penelitian ini menggunakan instrumen sebagai alat untuk mendukung penggunaan metode tersebut. Instrumen yang digunakan dalam penelitian ini adalah tes menulis teks laporan hasil observasi, lembar observasi aktivitas belajar siswa dan mengajar guru, lembar kuesioner respons siswa, dan pedoman wawancara. Instrumen tes praktik menentukan fakta dan opini digunakan dalam metode tes. Instrumen lembar observasi digunakan dalam metode observasi, instrumen lembar kuesioner digunakan dalam metode kuesioner, sedangkan pedoman wawancara digunakan dalam metode wawancara.

Setelah data terkumpul, selanjutnya akan dianalisis dengan menggunakan analisis data. Analisis penelitian ini disajikan secara deskriptif kualitatif dan kuantitatif. Analisis deskriptif kualitatif merupakan teknik analisis data yang menginterpretasikan sebuah fenomena secara umum untuk dicari kesimpulannya, sedangkan analisis deskriptif kuantitatif merupakan teknik analisis data yang menggunakan paparan sederhana yang berkaitan dengan angka-angka. Dalam penelitian ini, data hasil tes 
penggunaan ejaan dan tanda baca dalam menulis teks laporan hasil observasi dianalisis menggunakan teknik analisis data deskripstif kualitatif dan kuantitatif, aktivitas belajar siswa dan mengajar guru dengan penggunaan metode Jigsaw dianalisis menggunakan analisisis data deskriptif kualitatif dan kuantitatif. Data respons siswa dianalisis dengan teknik deskriptif kuantitatif dan kualitatif.

Kriteria keberhasilan belajar penggunaan ejaan dan tanda baca dalam menulis teks laporan hasil observasi adalah dengan adanya peningkatan berupa berkurangnya jumlah kesalahan penggunaan ejaan dan tanda baca dalam menulis teks laporan hasil observasi. Dengan tercapainya kriteria keberhasilan yang telah ditentukan di atas, berupa berkurangnya kesalahan penggunaan ejaan dan tanda baca dalam menulis teks laporan hasil observasi maka penelitian ini dapat dihentikan. Siklus tindakan yang mampu mencapai kesalahan paling sedikit dianggap sebagai tindakan terbaik yang memenuhi kriteria keberhasilan.

\section{ANALISIS DAN PEMBAHASAN}

Penelitian tindakan kelas ini bertujuan untuk meningkatkan kemampuan penggunaan ejaan dan tanda baca dalam menulis teks laporan hasil observasi siswa kelas X IPS SMA Negeri 1 Singaraja. Untuk mencapai tujuan ini, digunakan metode jigsaw. Penelitian ini dilaksanakan dalam dua siklus. Setiap siklusnya menggunakan empat tahap, yakni perencanaan, pelaksanaan, observasi/evaluasi, dan refleksi.

Penelitian ini diawali dengan tes awal (pretest). Selain itu penelitian ini juga menggunakan hasil wawancara dengan guru sebagai data awal. Berdasarkan tes awal (preteset) dan wawancara dengan guru tersebutlah yang dijadikan pijakan bahwa siswa memang memiliki kesulitan dan kurang memperhatikan penggunaan ejaan dan tanda baca dalam menulis teks laporan hasil observasi.

Siklus I dilaksanakan dalam satu kali pertemuan, yaitu pada 22 September 2017. Siklus I menunjukkan jumlah kesalahan penggunaan ejaan dan tanda baca siswa sejumlah 172 kesalahan. Apabila diklasifikasikan maka kesalahan tersebut, yaitu kesalahan penggunaan huruf capital sebanyak 47 kesalahan, kesalahan penggunaan preposisi sebanyak 31 kesalahan, kesalahan penggunaan tanda baca koma (,) sebanyak 70, dan kesalahan penggunaan tanda baca titik (.) sebanyak 24 kesalahan . Data ini menunjukkan bahwa siklus I masih banyak kesalahan penggunaan ejaan tanda baca. Hal ini menunjukkan siklus I belum berhasil.

Ketidakberhasilan siswa dalam penggunaan ejaan dan tanda baca dalam menulis teks laporan hasil observasi diidentifikasi penyebabnya. Berdasarkan hasil observasi yang dilakukan oleh observer terlihat bahwa semua item telah dilakukan oleh guru saat pembelajaran berlangsung. Bahkan, respons siswa terhadap pembelajaran menunjukkan skor 57 dan tergolong positif. Untuk itu, bisa dikatakan bahwa secara prosedur guru telah melakukan pembelajaran dengan baik pada saat pembelajaran. Oleh sebab itu, akar permasalahan yang dihadapi siswa perlu dikaji lebih mendalam.

Berdasarkan tulisan siswa terlihat bahwa ada beberapa yang menjadi kelemahan siswa saat menerapkan penggunaan ejaan dan tanda baca dalam menulis teks laporan hasil observasi. Kelemahan siswa tersebut diurutkan seperti yang terlihat di bawah ini.

1. Belum semua siswa yang menjadi tim ahli dapat menyampaikan kaidah penggunaan ejaan dan tanda baca yang diperoleh dari guru kepada anggota kelompoknya dengan baik, sehingga pemahaman masing-masing anggota kelompok tidak sama.

2. Masih banyak siswa yang ragu terhadap tulisan temannya, apakah tulisan tersebut menggunakan huruf kapital/kecil karena bentuk tulisan antara huruf besar/kecil dari teman tersebut hampir sama. Kondisi tersebut memicu si pengoreksi untuk mengonfirmasi kepada penulisnya. Tidak jarang terjadi bersitegang karena antara yang mengoreksi dan yang dikoreksi berbeda persepsi soal wujud huruf kapital/kecil.

3. Masih banyak siswa yang bingung menentukan preposisi dan imbuhan sehingga sering kali preposisi digabung dengan kata berikutnya yang seharusnya dipisah.

4. masih banyak siswa yang terpengaruh oleh kebiasaan yang salah sehingga membenarkan kesalahan tersebut. Kesalahan tersebut seperti kesalahan penggunaan tanda baca koma (,) yang terlalu banyak.

Oleh karena itu, setelah berembuk dengan guru pamong, diputuskan bahwa akan dilakukan perbaikan pada siklus II. Hal-hal yang diperbaiki pada siklus selanjutnya adalah sebagai berikut, 1) Tim ahli akan dijelaskan mengenai kesalahan konsep penulisan ejaan dan penggunaan huruf capital yang banyak terjadi pada siklus pertama dan dijelaskan konsep yang benar, 2) Tim ahli akan diingatkan mengenai tugas mereka sebagai tim ahli, 3) Siswa dan tim ahli akan dibimbing mengenai penggunaan dan perbedaan preposisi dan imbuhan, 4) Siswa dan tim ahli akan dibimbing mengenai penggunaan tanda baca koma(,), 5) Siswa akan dibimbing mengenai penggunaan huruf kapital pada kalimat. 
Siklus II dilaksanakan pada 26 September 2017. Siklus ini hanya dilakukan dalam satu kali pertemuan sama seperti siklus I. Pertemuan ini diawali dengan pemaparan hal-hal yang perlu diperbaiki siswa dalam penggunaan ejaan dan tanda baca dalam menulis teks laporan hasil observasi kepada tim ahli seperti yang telah direncanakan. Kemudian, dilanjutkan dengan pengambilan data.

Berdasarkan hasil observasi dari observer, pelaksanaan pembelajaran telah dilakukan oleh guru dengan sistematis dan semua langkah pembelajaran telah dilakukan. Selain itu, tidak ditemukan hal-hal yang perlu diperbaiki pada saat pelaksanaan pembelajaran. Respons siswa terhadap pembelajaran pada siklus II ini meningkat. Pada siklus I sebesar diperoleh skor rata-rata sebesar 57, sedangkan pada siklus II ini sebesar 63. Walaupun masih dalam kategori yang sama, yaitu positif. Namun, respons siswa ini sudah mengalami peningkatan dari siklus I. Dengan kata lain, pembelajaran yang dilakukan oleh guru sangat baik.

Hasil siklus II penggunaan ejaan dan tanda baca dalam menulis teks laporan hasil observasi oleh siswa pada siklus II menunjukkan jumlah kesalahan penggunaan ejaan dan tanda baca siswa sebanyak 52 kesalahan. Apabila diklasifikasikan maka kesalahan tersebut, yaitu kesalahan penggunaan huruf kapital sebanyak 12 kesalahan, kesalahan penggunaan preposisi sebanyak 10kesalahan, kesalahan penggunaan tanda baca koma (,) sebanyak 20 kesalahan, dan kesalahan penggunaan tanda baca titik (.) sebanyak 10 kesalahan. Dengan kata lain, siklus II ini telah berhasil.

Siklus II ini dinyatakan telah berhasil karena terjadi peningkatan dengan berkurangnya jumlah kesalahan siswa dalam menggunakan ejaan dan tanda baca dari sejak pretest, siklus I, dan siklus II. Walaupun ada beberapa siswa yang memiliki kesalahan dalam penggunaan ejaan dan tanda baca. Selain hal yang telah dipaparkan di atas, hasil siklus II berdasarkan angket yang diisi oleh siswa maka dapat dikatakan bahwa penggunaan metode jigsaw dapat meningkatkan respons siswa dalam belajar, khsusnya terkait penggunaan ejaan dan tanda baca dalam menulis teks laporan hasil observasi.

Hal-hal yang paparkan di atas adalah seputar hasil penelitian ini dan korelasinya dengan hasil angket dan hasil observasi oleh observer. Secara ringkas peningkatan kemampuan penggunaan ejaan dan tanda baca dalam menulis teks laporan hasil observasi siswa kelas X IPS SMA Negeri 1 Singaraja dapat dilihat pada Tabel di bawah ini.

Tabel 1 Perbandingan Kesalahan Penggunaan Ejaan dan Tanda Baca dalam Menulis Teks Laporan Hasil Observasi Tiap Siklus

\begin{tabular}{lcc}
\hline Aspek yang Dibandingkan & Siklus I & Siklus II \\
\hline Kesalahan Huruf Kapital & 47 & 12 \\
Kesalahan Preposisi & 31 & 10 \\
Keslahan Tanda Baca Koma (.) & 70 & 20 \\
Kasalahan Tanda Baca Titik (.) & 24 & 10 \\
Total & $\mathbf{1 7 2}$ & $\mathbf{5 2}$ \\
\hline
\end{tabular}

Hasil penelitian yang dipaparkan di atas jika dibandingkan dengan penelitian yang dilakukan oleh Heri Kustomo (2012) maka hasil penelitian ini lebih baik. Penelitian yang dilakukan oleh Heri Kustomo berjudul Peningkatan Kemampuan Menggunakan Ejaan dan Tanda Baca dalam Menulis Pengalaman Pribadi dengan Metode Jigsaw Siswa Kelas VII-B SMP Negeri 1 Rengel Kabupaten Tuban. Hasilnya adalah jumlah kesalahan dalam penggunaan ejaan dan tanda baca pada siklus I sebanyak 465 dan meningkat dengan berkurangnya kesalahan siswa pada siklus II menjadi 73. Sedangkan, penelitian ini kesalahan siswa dalam menggunakan ejaan dan tanda baca sejumlah 172 pada siklus I dan meningkat dengan berkurangnya kesalahan siswa pada siklus II menjadi 52 kesalahan. Perbedaan hasil ini bisa terjadi karena penelitian ini karena subjek penelitian ini berbeda sehingga hasilnya juga memungkinkan berbeda.

Berdasarkan hasil perbandingan di atas dapat disimpulkan bahwa hasil belajar siswa berupa penggunaan ejaan dan tanda baca dalam menulis teks laporan hasil observasi akan lebih baik jika menerapkan metode pembelajaran Jigsaw. 


\section{KESIMPULAN}

Berdasarkan hasil dan pembahasan penelitian tindakan kelas tehadap proses pembelajaran untuk meningkatkan kemampuan menggunakan ejaan dan tanda baca menggunakan metode Jigsaw pada kelas X IPS SMA Negeri 1 Singaraja dapat disimpulkan sebagai berikut.

Terjadi peningkatan kemampuan menggunakan ejaan dan tanda baca dalam menulis teks laporan hasil observasi dengan metode Jigsaw pada kelas X IPS SMA Negeri 1 Singaraja yaitu: siswa yang melakukan kesalahan dalam penggunaan ejaan dan tanda baca menurun dari 172 pada siklus I menjadi 52 kesalahan pada siklus II. Apabila diklasifikasikan, yaitu 1) kesalahan penggunaan huruf kapital/kecil mengalami penurunan dari 47 kesalahan pada siklus I menjadi 12 kesalahan pada siklus II, 2) siswa yang melakukan kesalahan penggunaan kata depan dari 31 kesalahan pada siklus I menjadi 10 kesalahan pada siklus II, 3) Siswa yang melakukan kesalahan penggunaan tanda baca berupa koma (,) dari 70 kesalahan pada siklus I menjadi 20 kesalahan pada siklus II. 4) Siswa yang melakukan kesalahan penggunaan tanda baca berupa titik (.) dari 24 kesalahan pada siklus I menjadi 10 kesalahan pada siklus II.

Respons Siswa dalam pembelajaran penggunaan ejaan dan tanda baca dalam menulis teks laporan hasil observasi juga meningkat ketika guru menggunakan metode Jigsaw dalam proses pembelajaran. Hal ini dapat dilihat berdasarkan angket yang diisi oleh siswa. Berdasarkan angket yang diisi siswa didapatkan hasil sebagai berikut:

Dengan berpedoman pada kriteria respons siswa terhadap pelaksanaan tindakan, maka penelitian ini dinyatakan sudah positif dari segi respons dan sudah ada peningkatan respons siswa dari rata-rata 57 pada siklus I menjadi 63 pada siklus II. Walaupun masih dalam kriteria yang sama, yaitu kriteria positif.

Berdasarkan temuan-temuan dalam penelitian ini, disampaikan beberapa saran sebagai berikut. 1) Sekolah hendaknya memotivasi guru untuk aktif menggunakan metode dan menerapkan pembelajaran yang memanfaatkan tutor sebaya.2) Guru hendaknyadapat meningkatkan kemampuan penggunaan ejaan dan tanda baca siswa dalam menulis dengan menggunakan metode Jigsaw. 3) Guru diharapkan dapat menemukan metode pembelajaran yang sesuai dengan materi yang diajarkan, tetapi tidak membuat jenuh siswa dengan menggunakan metode pembelajaran yang monoton. 4) Segera setelah hasil evaluasi selesai dikoreksi, hasil pekerjaan siswa sebaiknya dibagikan kembali agar siswa mengetahui kesalahannya dan termotivasi untuk mempertahankan atau meningkatkan hasil belajarnya. 5) Guru lebih intensif dalam memberikan motivasi dan mengarahkan siswa dengan cara berkeliling dari semua sudut serta memantau setiap siswa sehingga jika ada yang mengalami kesulitan peneliti dapat memberi bantuan. 6) Guru hendaknya mampu mengelola waktu dengan sebaik mungkin sehingga proses pembelajaran dapat terlaksana secara efektif. 7) Peneliti hendaknya dapat menyebarluaskan hasil penelitian tentang penggunaan metode Jigsaw kepada semua guru SMA Negeri 1 Singaraja, khususnya guru Bahasa Indonesia untuk membantu keberhasilan penggunaan ejaan dan tanda baca pada materi menulis.

\section{DAFTAR PUSTAKA}

Arikunto, suharsimi, dkk. 2006. Penelitian Tidakan Kelas. Jakarta: PT.Bumi Aksara

Darmadi, Kaswan. 1996. Meningkatkan Kemampuan Menulis. Yogyakarta: Andi.

Depdikbud. 2007. Kamus Besar Bahasa Indonesia. Jakarta: Pusat Bahasa.

Djibran, Fahd. 2008. Writing is Amazing. Yogyakarta: Juxtapose.

Enre, Fachruddin Ambo. 1988. Dasar-Dasar Keterampulan Menulis. Jakarta: Depdikbud.

Hasnun, H. Anwar. 2006. Pedoman Menulis untuk Siswa SMP dan SMA.Yogyakarta: Andi.

Iskandarwassid dan Dadang Sunendar. 2008. Strategi Pembelajaran Bahasa. Bandung: PT Remaja Rosdakarya.

Keraf, Gorys. 2004. Komposisi: Sebuah Pengantar Kemahiran Berbahasa. Flores: Nusa Indah.

Kosasih, E. 2012. Dasar- Dasar Keterampilan Menulis . Bandung : Yrama Widya. 
Kustomo, Heri.2012 .Peningkatan Kemampuan Menggunakan Ejaan dan Tanda Baca dalam Menulis Pengalaman Pribadi dengan Metode Jigsaw Siswa Kelas VII-B SMP Negeri 1 Rengel Kabupaten Tuban. Surabaya: Unesa

Lie, Anita. 2003. Cooperative Learning: Mempraktikkan Cooperative Learning di Ruang-Ruang Kelas (cetakan kedua). Jakarta: Grasindo.

Mustakim. 2001. Psikologi Pendidikan. Yogyakarta : Pustaka Pelajar.

Musaddat. 2008. Aplikasi Bahasa Indonesia: Pemahaman Ke Arah Penyusunan Karya Ilmiah. Mataram: Universitas Mataram

Margono. 2004. Metode Penelitian Pendidikan. Jakarta: Rienika Cipta.

Nurgiyantoro, Burhan. 2013. Penilaian Pembelajaran Bahasa Berbasis Kompetensi. Yogyakarta: BPFE.

Nuryeni. 2016. Peningkatan Keterampilan Menyusun Teks Laporan Hasil Observasi Bermuatan Budaya Melalui Discovery Learning Berbantuan Puzzle pada Siswa Kelas VII H SMP Negeri 18 Semarang. Semarang: Unnes

Slavin, Robert E. 1995. Cooperative Learning: Theory Research and Practice. Massachusetts: Allyn and Bacon.

Suprijono, Agus. 2010. Cooperative Learning. Yogyakarta: Pustaka Pelajar

Suriamiharja, Agus, dkk. 1996. Petunjuk Praktis Menulis. Jakarta: Depdikbud.

Tarigan, Henry Guntur. 2008. Menulis sebagai Suatu Keterampilan Berbahasa. Bandung: Angkasa. 